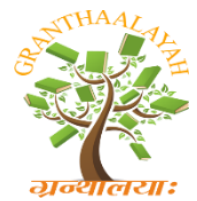

\author{
INTERNATIONAL JOURNAL OF R
GRANTHAALAYAH \\ A knowledge Repository
}

Science

\title{
A STOCHASTIC MULTI-CRITERIA DECISION-MAKING ANALYSIS FOR A WAREHOUSE LOCATION SELECTION PROBLEM: A CASE STUDY
}

\author{
Şeyma Emeç *1, Gökay Akkaya ${ }^{2}$ \\ ${ }^{* 1,2}$ Department of Industrial Engineering, Ataturk University, Turkey
}

\begin{abstract}
The problem of a warehouse location selecting which has a significant impact on logistics costs is an important decision problem based on the best choice of alternatives under multiple conflicting criteria. Multiple-criteria decision-making (MCDM) methods are used as a solution approach for the decision problems including several criteria. In this study, a new stochastic multi-criteria decision-making approach has been developed to solve the warehouse location selection problem (WLSP) in the stochastic environment which contains uncertain situations. In the proposed approach, the SAHP (Stochastic Analytic Hierarchy Process) method was used to calculate the weight of criteria, and the alternatives were ranked and evaluated by fuzzy MOORA (MultiObjective Optimization by Ratio Analysis). The proposed approach is applied to warehouse selection problem of a supermarket chain located in Turkey. The results of the research indicated that $\mathrm{A} 2$ is the best alternative. It can be said that the proposed method can be applied to the real life problems because it found a suitable solution to the problem.
\end{abstract}

Keywords: Fuzzy MOORA Stochastic AHP; The Warehouse Location Selection.

Cite This Article: Şeyma Emeç, and Gökay Akkaya. (2019). "A STOCHASTIC MULTICRITERIA DECISION-MAKING ANALYSIS FOR A WAREHOUSE LOCATION SELECTION PROBLEM: A CASE STUDY." International Journal of Research - Granthaalayah, 7(12), 133-143. https://doi.org/10.29121/granthaalayah.v7.i12.2019.307.

\section{Introduction}

In the globalizing world, many institutions and organizations are able to flow products, services and information easily by reaching the customer network thanks to effective communication opportunities and especially with the developments in the field of informatics. The intense and mobile information environment that has continued with globalization has led to the rapid development of a whole new economic structure. Within this economic structure, companies focus on reducing costs and ensuring customer satisfaction has led to the increasing importance of logistics. Storage is seen as the most important function in logistics processes. Warehousing processes have an important place in logistics systems as a separate operating activity as they 
require efficient product movement in their structures and cause maximum space loss. This is the reason why storage is a critical point in terms of providing quality service and profit in the activities of enterprises.

Multi-criteria decision making (MCDM) techniques are the techniques that help determine the most appropriate option or options by considering the criteria that can affect each other among many options.

In this context, in this study, a model was created using SAHP and Fuzzy MOORA (F-MOORA) method for distribution network design which provides connection between warehouses and customer which are the most important elements of logistics distribution problem. Two methods are that SAHP and Fuzzy MOORA (F-MOORA) to rank alternatives was hybridized in this study. This hybrid method has not been used in the literature before, to our knowledge.

Considering the literature of warehouse location selection problem, it is seen that different methods are used; the article studied a successful application of multi-criteria Choquet integral to a real warehouse location selection problem of a big Turkish logistic firm [1]. Tabu Search algorithm was used for warehouse layout problem [2]. Particle swarm optimization was used an automobile spare part warehouse location problem [3]. It was presented a model that looks for the optimal allocation of goods in order to maximize the storage space available within the restrictions of the warehouse. Computational tests performed on a set of randomly generated and real warehouse instances showed the effectiveness of the proposed methods [4]. Rath and Gutjahr developed a "math-heuristic" for a three-objective ware- house location-routing problem in disaster relief [5]. A continuous approximation model was proposed for warehouse location. This model was applied to the real case of a company [6].

\section{Materials and Methods}

In this study, SAHP and F-MOORA techniques which are MCDM were used for a warehouse location selection problem.

There are many studies in different fields related to multi-criteria decision making (MCDM). The some of these studies: smart wristband selection [7], ERP deployment strategy selection [8], healthcare waste treatment technology selection [9], selection of on-site energy generation technology [10], evaluation of framed building types [11], strategic alliance partner selection in third-party logistics [12], logistics center location selection [13], the medical company selection [14], cargo company selection[15], location selection for underground waste containers [16], warehouse location selection [17], industrial engineering sector choosing [18], personnel selection [19], location selection for a yarn factory[20], data center location selection [21].

The stages of the proposed method for the appropriate warehouse location selection are described in Figure 1. In the first stage, criteria and alternatives are determined by the decision makers. In the second stage, criteria weights are calculated by using the SAHP technique. In the third stage, the most suitable alternative is selected by using the F-MOORA. 


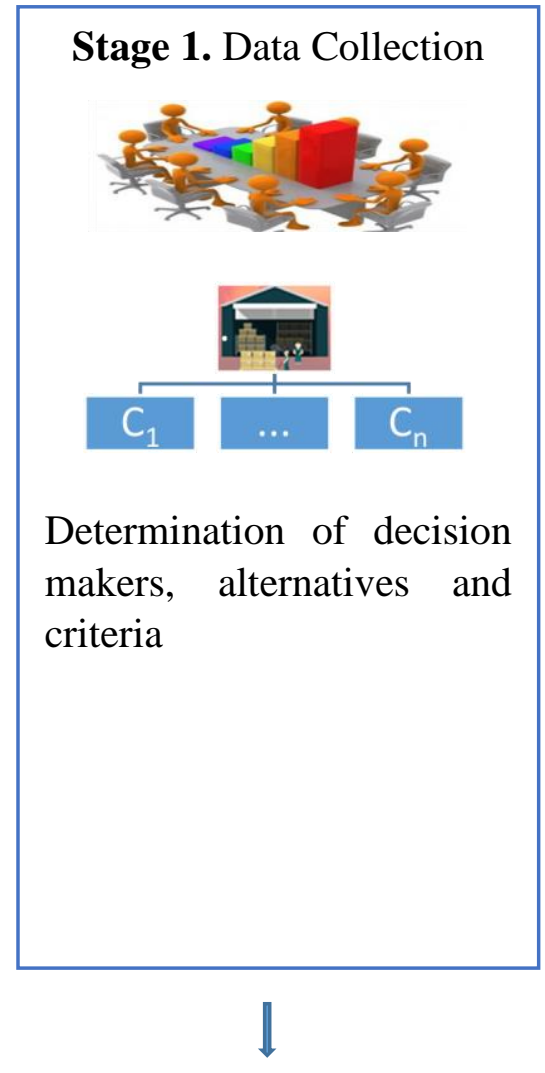

Stage 2. Determine the criteria weights using SAHP

Stage 3. Selection of the best warehouse location selection by Fuzzy MOORA method

\section{Step 1. Compare elements using the pairwise comparison scale.}

Step 2. Convert imprecise preferences of experts into stochastic comparisons

Step 3. Stochastic pairwise comparisons transformed pairwise distributed comparisons $\left(q_{i j}\right)$

$\mathrm{B}\left(\&_{i j} \mid \alpha, \beta, \mathrm{LL}, \mathrm{UL}\right), \mathrm{LL} \leq$ $\&_{i j} \leq \mathrm{UL}$ and $\alpha, \beta \geq 1$.

lower limit (LL), most likely (ML) and upper limit (UL)

Step 4. Convert beta distributed pairwise comparisons to crisp values. $a_{i j}=L L_{i j}+\mathrm{m}\left(\hat{\alpha}_{i j}, \hat{\beta}_{i j}\right) *\left(\mathrm{UL}_{i j}\right.$ The median of beta distribution, $\mathrm{m}\left(\alpha_{i j}, \beta_{i j}\right)$,
Table 1: Saaty's pairwise comparison scale (1977)

\begin{tabular}{||l|l|}
\hline $\begin{array}{l}\text { Intensity of } \\
\text { importance }\end{array}$ & Definition \\
\hline 1 & $\begin{array}{l}\text { Equal } \\
\text { importance }\end{array}$ \\
\hline 3 & $\begin{array}{l}\text { Moderate } \\
\text { importance }\end{array}$ \\
\hline 5 & $\begin{array}{l}\text { Strong } \\
\text { importance }\end{array}$ \\
\hline 7 & $\begin{array}{l}\text { Very } \\
\text { strong } \\
\text { importance }\end{array}$ \\
\hline 9 & $\begin{array}{l}\text { Extreme } \\
\text { importance }\end{array}$ \\
\hline
\end{tabular}

Figure 1: The stages of the proposed method

\section{Stage 3. Fuzzy MOORA}

In this study, F-MOORA method was used for evaluating the alternatives. The steps of F-MOORA methods are described as follows.

Step 1. Establishment of fuzzy decision matrix (FDM) using triangular fuzzy numbers [22]. 


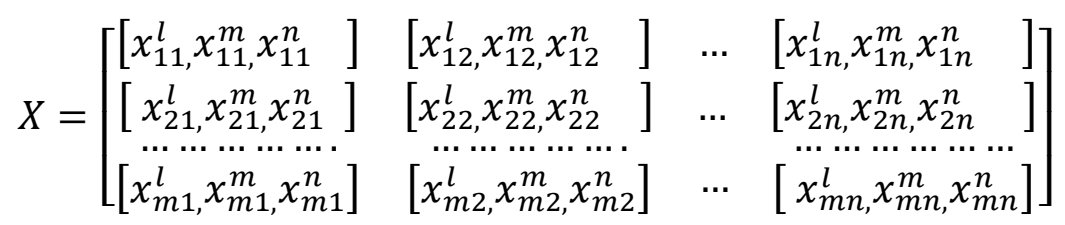

DOI: $10.5281 /$ zenodo.3595343

$x_{i j}^{l}, x_{i j}^{m}, x_{i j}^{n}$ values in the FDM, represents small, medium and large value in triangular fuzzy numbers for $\mathrm{i}^{\text {th }}$ alternative in terms of $\mathrm{j}^{\text {th }}$ criteria, respectively. Decision- makers have benefited from the scale in table 2 in the creation of the fuzzy decision matrix.

Table 2: Linguistic variables used for alternative assessment

\begin{tabular}{|l|l|}
\hline Linguistic Variables & Triangular Fuzzy Numbers \\
\hline Very weak/low & $(0,0,1)$ \\
\hline weak & $(0,1,3)$ \\
\hline Moderate weak & $(1,3,5)$ \\
\hline Moderate & $(3,5,7)$ \\
\hline Moderate well & $(5,7,9)$ \\
\hline Well & $(7,9,10)$ \\
\hline Very well & $(9,10,10)$ \\
\hline
\end{tabular}

Step 2: vector normalization is performed and normalized FDM is calculated [22].

$r_{i j}^{l}=\frac{x_{i j}^{l}}{\sqrt{\sum_{i=1}^{m}\left[\left(x_{i j}^{l}\right)^{2}+\left(x_{i j}^{m}\right)^{2}+\left(x_{i j}^{n}\right)^{2}\right]}}$

$r_{i j}^{l}=\frac{x_{i j}^{m}}{\sqrt{\sum_{i=1}^{m}\left[\left(x_{i j}^{l}\right)^{2}+\left(x_{i j}^{m}\right)^{2}+\left(x_{i j}^{n}\right)^{2}\right]}}$

$r_{i j}^{l}=\frac{x_{i j}^{n}}{\sqrt{\sum_{i=1}^{m}\left[\left(x_{i j}^{l}\right)^{2}+\left(x_{i j}^{m}\right)^{2}+\left(x_{i j}^{n}\right)^{2}\right]}}$

Step 3: weighted normalized FDM is calculated [22].

$v_{i j}^{l}=w_{j} r_{i j}^{l}$

$v_{i j}^{m}=w_{j} r_{i j}^{m}$

$v_{i j}^{n}=w_{j} r_{i j}^{n}$

Step 4: ranking is calculated for all alternatives in terms of cost and benefit criteria For benefit criteria [22].

$s_{i}^{+l}=\sum_{j=1}^{n} v_{i j}^{l} \mid j \in j^{\max }$ 
$s_{i}^{+m}=\sum_{j=1}^{n} v_{i j}^{m} \mid j \in j^{\max }$

$s_{i}^{+n}=\sum_{j=1}^{n} v_{i j}^{n} \mid j \in j^{\max }$

For cost criteria

$s_{i}^{-l}=\sum_{j=1}^{n} v_{i j}^{l} \mid j \in j^{\text {min }}$

$s_{i}^{-m}=\sum_{j=1}^{n} v_{i j}^{m} \mid j \in j^{m i n}$

$s_{i}^{-n}=\sum_{j=1}^{n} v_{i j}^{n} \mid j \in j^{\text {min }}$

Step 5: Performance points for all the alternatives are calculated. For performance scores, benefits and costs of criteria values for alternatives are defuzzified by using the vertex method [22].

$S_{i}\left(s_{i}^{+}, s_{i}^{-}\right)=\sqrt{\frac{1}{3}\left[\left(s_{i}^{+l}-s_{i}^{-l}\right)^{2}+\left(s_{i}^{+m}-s_{i}^{-m}\right)^{2}+\left(s_{i}^{+n}-s_{i}^{-n}\right)^{2}\right]}$

Step 6: Alternatives are ranked according to their performance scores. Alternative which has the highest performance scores is preferred [23].

\subsection{Application}

In the first stage of the application, decision-team is created which consists of 3 decision makers. 17 criteria and four alternative locations which are determined by this decision team are presented Figure 2. In the second stage, SAHP technique was used to determine criteria weights. The steps of SAHP were taken from the work of [17]. 


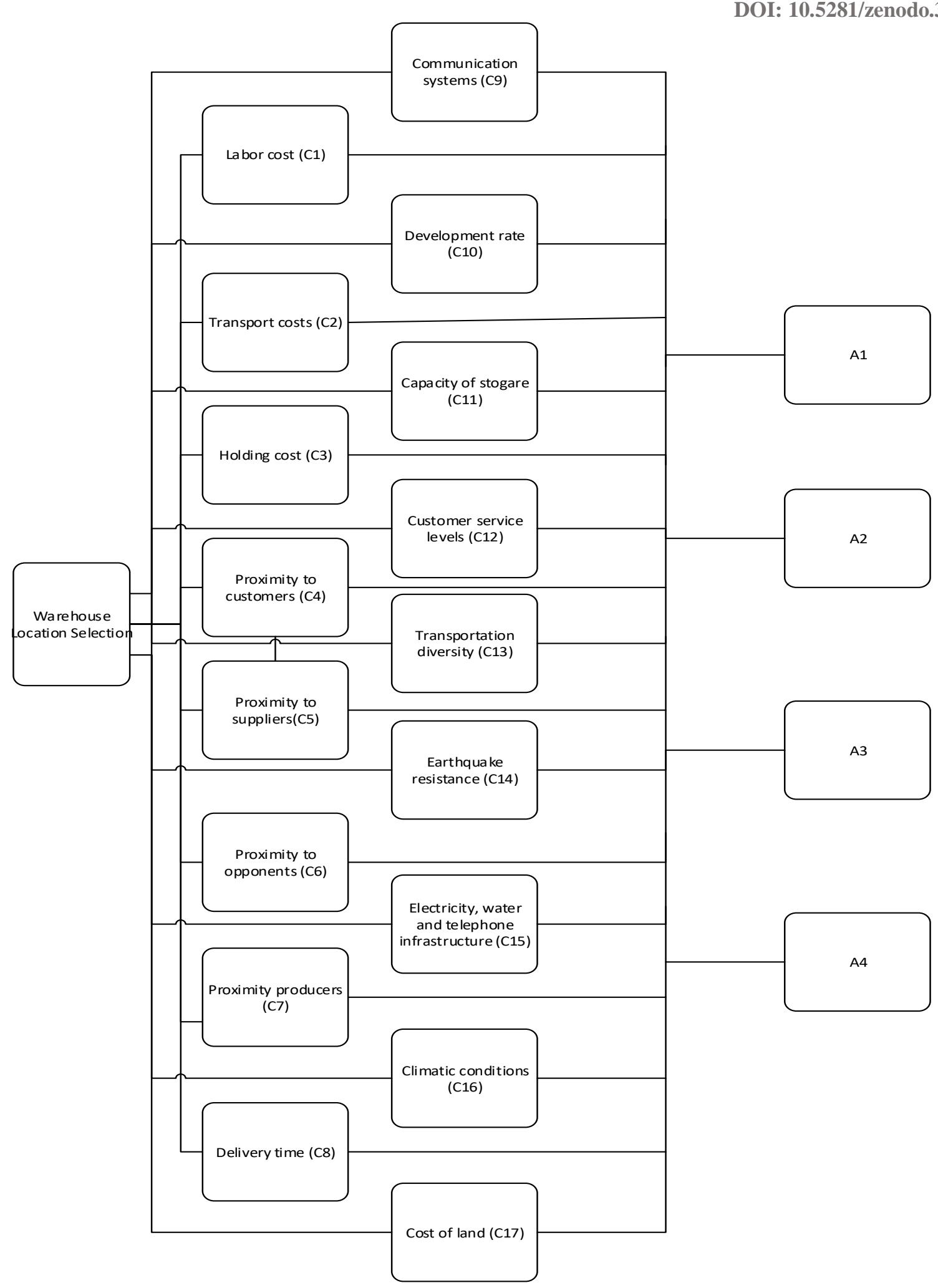

Goal

Criteria

Alternatives

Figure 2: The decision hierarcy of the WLSP 


\section{Results and Discussions}

Decision makers evaluated the criteria by using scale in Table 1 . These values were converted to beta distribution by applying equality 5-7 to stochastic PCM. Table 2 presents stochastic PCM of decision maker 1 following the conversion to the beta distribution. The values in Table 2 were converted to net value by using equality 9-10. Table 3 presents net values.

Table 2: The form of PCM converted to beta distribution of decision maker 1

\begin{tabular}{|l|l|l|l|l|l|l|}
\hline & C1 & C2 & C3 & & C16 & C17 \\
\hline C1 & 1 & $1 / 9$ & $1 / 9$ & $\ldots$ & $1 / 9$ & $1 / 9$ \\
\hline C2 & 9 & 1 & $\mathrm{~B}(1.96,0.37,1 / 8,1 / 6)$ & $\ldots$ & 2 & $\mathrm{~B}(1,1,8,9)$ \\
\hline C3 & 9 & $\mathrm{~B}(2.49,2.49,6,8)$ & 1 & $\ldots$ & $\mathrm{B}(1,1,1 / 2,1)$ & $\mathrm{B}(1,1,1 / 2,1)$ \\
\hline$\vdots$ & $\vdots$ & $\vdots$ & $\vdots$ & $\vdots$ & $\vdots$ & $\vdots$ \\
\hline C16 & 9 & $1 / 2$ & $\mathrm{~B}(1,1,1,2)$ & & 1 & $1 / 8$ \\
\hline C17 & 9 & $\mathrm{~B}(1,1,1 / 9,1 / 8)$ & $\mathrm{B}(1,1,1,2)$ & & 8 & 1 \\
\hline
\end{tabular}

Table 3: The Form tf Beta Distribution PCM Converted to Net Value of Decision maker 1

\begin{tabular}{|l|l|l|l|l|l|l|}
\hline & C1 & C2 & C3 & & C16 & C17 \\
\hline C1 & 1 & $1 / 9$ & $1 / 9$ & $\ldots$ & $1 / 9$ & $1 / 9$ \\
\hline C2 & 9 & 1 & 0,16 & $\ldots$ & 2 & 8,50 \\
\hline C3 & 9 & 7 & 1 & $\ldots$ & 0,75 & 0,75 \\
\hline$\vdots$ & $\vdots$ & $\vdots$ & $\vdots$ & $\vdots$ & $\vdots$ & $\vdots$ \\
\hline C16 & 9 & $1 / 2$ & 1,50 & $\ldots$ & 1 & $1 / 8$ \\
\hline C17 & 9 & 0,12 & 1,50 & $\ldots$ & 8 & 1 \\
\hline
\end{tabular}

PCM of decision makers are combined with the geometric mean method. Table 4 and Table 5 present combined PCM and normalized PCM, respectively.

Table 4: Combined PCM

\begin{tabular}{|l|l|l|l|l|l|l|}
\hline & C1 & C2 & C3 & & C16 & C17 \\
\hline C1 & 1,00 & 0,12 & 0,12 & $\ldots$ & 0,12 & 0,11 \\
\hline C2 & 8,14 & 1,00 & 0,15 & $\ldots$ & 0,57 & 1,92 \\
\hline C3 & 8,31 & 6,80 & 1,00 & $\ldots$ & 0,91 & 0,40 \\
\hline$\vdots$ & $\vdots$ & $\vdots$ & $\vdots$ & $\vdots$ & $\vdots$ & $\vdots$ \\
\hline C16 & 8,14 & 1,74 & 1,14 & $\ldots$ & 1,00 & 0,12 \\
\hline C17 & 8,83 & 0,50 & 2,73 & $\ldots$ & 8,16 & 1,00 \\
\hline
\end{tabular}

Table 5: Normalized PCM.

\begin{tabular}{|l|c|c|c|c|c|c|}
\hline & C1 & C2 & C3 & & C16 & C17 \\
\hline C1 & 0,02 & 0,01 & 0,01 & $\ldots$ & 0,01 & 0,02 \\
\hline C2 & 0,14 & 0,07 & 0,01 & $\ldots$ & 0,02 & 0,29 \\
\hline C3 & 0,15 & 0,47 & 0,10 & $\ldots$ & 0,04 & 0,06 \\
\hline$\vdots$ & $\vdots$ & $\vdots$ & $\vdots$ & $\vdots$ & $\vdots$ & $\vdots$ \\
\hline C16 & 0,14 & 0,12 & 0,11 & $\ldots$ & 0,04 & 0,02 \\
\hline C17 & 0,16 & 0,03 & 0,27 & $\ldots$ & 0,34 & 0,15 \\
\hline
\end{tabular}


Weight values of each criterion were calculated by applying calculation in AHP method to normalized PCM. Calculated weight values of the criteria are shown Figure 3. This value is used in weight found by calculating the F-MOORA.

Decision team evaluated alternatives and formed FDM by using linguistic variables in Table 2. FDM of decision team are combined and it is shown in the Table 6.

Table 6: Combined FDM

\begin{tabular}{|l|l|l|l|l|l|l|}
\hline & $\mathbf{C 1}$ & $\mathbf{C 2}$ & $\mathbf{C 3}$ & & $\mathbf{C 1 6}$ & $\mathbf{C 1 7}$ \\
\hline A1 & $(3,6.8,10)$ & $(5,7.6,10)$ & $(3,7.4,10)$ & $\ldots$ & $(3,6.3,10)$ & $(0,4.3,10)$ \\
\hline A2 & $(3,7.7,10)$ & $(9,10,10)$ & $(9,10,10)$ & $\ldots$ & $(9,10,10)$ & $(9,10,10)$ \\
\hline A3 & $(3,5,7)$ & $(0,0,3)$ & $(0,0,7)$ & $\ldots$ & $(0,1,3)$ & $(0,1,3)$ \\
\hline A4 & $(3,6.1,10)$ & $(7,9,10)$ & $(3,7.4,10)$ & $\ldots$ & $(7,9,10)$ & $(3,5,7)$ \\
\hline
\end{tabular}

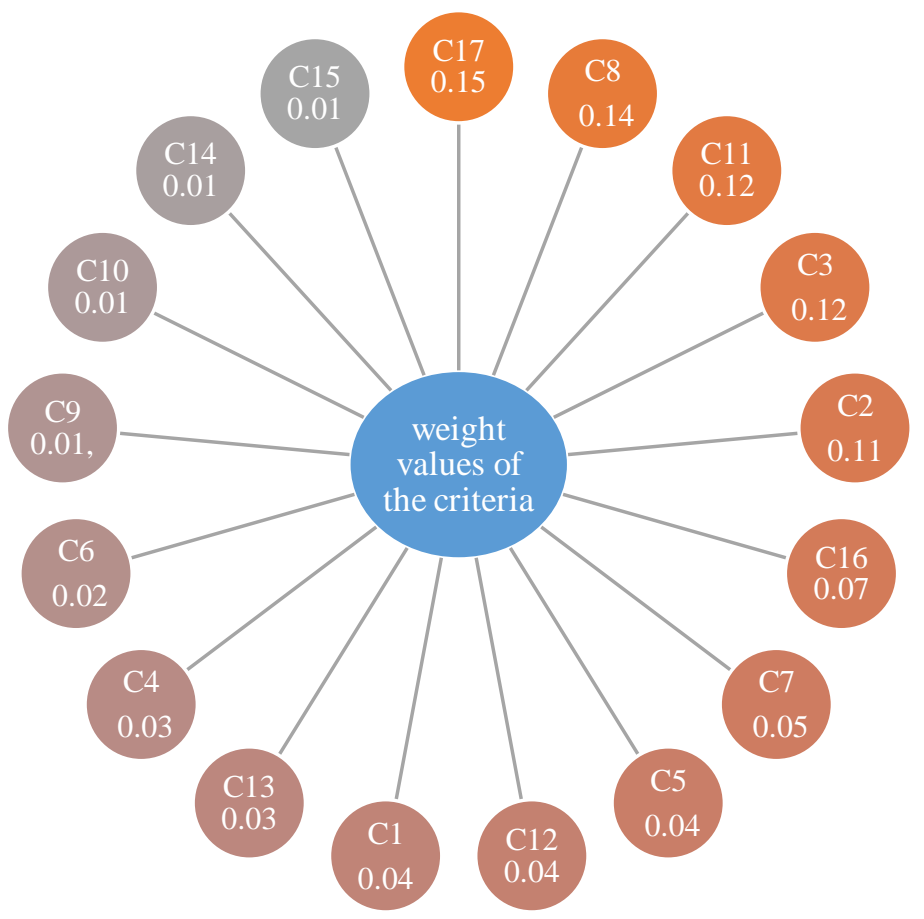

Figure 3: Weight Values of the Criteria

MOORA calculations were used as proposed by [22]. FDM were normalized by using equality 24 and that is presented in the Table 7.

Table 7: Normalized FDM

\begin{tabular}{|c|c|c|c|c|c|c|c|c|c|}
\hline & C1 & $\mathrm{C2}$ & & C3 & & & C16 & & C17 \\
\hline A1 & \begin{tabular}{|l|}
$(0.128$, \\
$0.289,0.425)$ \\
\end{tabular} & $\begin{array}{l}(0.189, \\
0.377)\end{array}$ & 0.288 & \begin{tabular}{|l}
$(0.117$, \\
$0.390)$ \\
\end{tabular} & 0.289 & . & $\begin{array}{l}(0.116, \\
0.386)\end{array}$ & 0.243 & $(0,0.194,0.450)$ \\
\hline A2 & \begin{tabular}{|l|}
0.128, \\
$0.328,0.425)$ \\
\end{tabular} & $\begin{array}{l}(0.340, \\
0.377 \\
\end{array}$ & 0.377 & \begin{tabular}{|l|}
$(0.351$, \\
$0.391)$ \\
\end{tabular} & 0.391, & $\ldots$ & $\begin{array}{l}(0.374, \\
0.386)\end{array}$ & 0.386 & \begin{tabular}{|l}
0.405 \\
$0.450)$ \\
\end{tabular} \\
\hline A3 & \begin{tabular}{|l|}
$(0.128$, \\
$0.213,0.298)$
\end{tabular} & $(0,0,0.113)$ & & $(0,0,0.273)$ & & $\ldots$ & $(0,0.039$ & 16) & $(0,0.045,0.135)$ \\
\hline
\end{tabular}




\begin{tabular}{|l|l|ll|ll|l|ll|ll|}
\hline A4 & $(0.128$, & $(0.264$, & 0.340, & $(0.118$, & 0.289, & $\ldots$ & $(0.270$, & 0.347, & $(0.135$, & 0.225, \\
& $0.259,0.425)$ & $0.377)$ & & $0.391)$ & & & $0.386)$ & & $0.315)$ & \\
\hline
\end{tabular}

Weighted normalized FDM obtained by applying equality 5-7 to normalized FDM and Table 8 shows weighted normalized FDM.

Table 8: Weighted Normalized FDM.

\begin{tabular}{|c|c|c|c|c|c|c|}
\hline & C1 & C2 & C3 & & C16 & C17 \\
\hline A1 & $\begin{array}{ll}0.005, & 0.012 \\
0.017) & \\
\end{array}$ & $\begin{array}{l}(0.021, \\
0.041)\end{array}$ & $\begin{array}{l}(0.014, \\
0.047)\end{array}$ & .. & $\begin{array}{l}(0.008, \\
0.027)\end{array}$ & $(0,0.029,0.068)$ \\
\hline A2 & \begin{tabular}{|ll}
0.005, & 0.013, \\
$0.017)$ & \\
\end{tabular} & $\begin{array}{l}(0.037 \\
0.041)\end{array}$ & \begin{tabular}{|l|}
$(0.042$ \\
$0.047)$ \\
\end{tabular} & & \begin{tabular}{|l}
$(0.026$, \\
$0.027)$
\end{tabular} & \begin{tabular}{|l}
$(0.061$, \\
$0.068)$
\end{tabular} \\
\hline A3 & $\begin{array}{ll}(0.005, & 0.008, \\
0.012) & \\
\end{array}$ & $(0,0,0.012)$ & $(0,0,0.033)$ & .. & $(0,0.003,0.008)$ & $(0,0.007,0.020)$ \\
\hline A4 & $\begin{array}{ll}(0.005, & 0.01, \\
0.017) & \end{array}$ & $\begin{array}{l}(0.029, \\
0.041)\end{array}$ & \begin{tabular}{|l}
$(0.014$, \\
$0.047)$
\end{tabular} & .. & $\begin{array}{l}(0.019, \\
0.027)\end{array}$ & \begin{tabular}{|l}
$(0.020$, \\
$0.047)$
\end{tabular} \\
\hline
\end{tabular}

Finally, equations (8) - (13) were obtained in terms of the costs and benefits of each alternative ranking, performance scores of each alternative was obtained by using equation 14. Table 9 represents performance ranking of alternatives ranking.

Table 9: Performance Ranking of Alternatives Ranking.

\begin{tabular}{|l|l|l|l|l|}
\hline Alternatives & \multicolumn{1}{|c|}{$\mathbf{S}^{*}$} & \multicolumn{1}{|c|}{$\mathbf{S}^{-}$} & S & Rank \\
\hline A1 & $(0.065,0.151,0.236)$ & $(0.04,0.108,0.181)$ & 0.043 & 2 \\
\hline A2 & $(0.186,0.226,0.235)$ & $(0.152,0.177,0.181)$ & 0.046 & 1 \\
\hline A3 & $(0,0.014,0.104)$ & $(0.005,0.016,0.082)$ & 0.013 & 3 \\
\hline A4 & $(0.088,0.127,0.165)$ & $(0.073,0.123,0.16)$ & 0.009 & 4 \\
\hline
\end{tabular}

A2 has the highest ranking points in four different region ranking. It is followed by A1, A3, A4 options. Supermarket's owner should select A2 region for warehouse location selection according to the results obtained from F-MOORA method.

In this paper, a new model that will help managers to make a decision regarding warehouse location selection has been developed. Developed models involve the hybridization of SAHP and F-MOORA methods. Studies in the literature previously, SAHP have been used rarely and have not been used in any application with fuzzy MOORA method combination. This study is intended to be the first study in the literature in this respect.

\section{Conclusions and Recommendations}

In today's conditions, firms must constantly question their costs and be more careful when making decisions in order to survive in a globalized world. Hence, effective methods should be used for decisions to be taken and decision-making process should be carried out carefully.

A common problem that faced by decision makers is bounded rationalness. This means that decision maker's choices are limited. This lead to crisp as well as imprecise pairwise comparisons. Therefore, we propose a beta distribution to model the varying stochastic choices of the decision 
maker. By doing this, wider choice options were provided for decision makers. It is suggested that a combination of SAHP and F-MOORA can be used for different types of problems in future studies. Also, a combination of other MCDM techniques

\section{References}

[1] Demirel, T., N.Ç. Demirel, and C. Kahraman, Multi-criteria warehouse location selection using Choquet integral. Expert Systems with Applications, 2010. 37(5): p. 3943-3952.

[2] Nehzati, T., H. Rashidi-Bajgan, and N. Ismail, Development of a decision support system using Tabu Search algorithm for the warehouse layout problem. Journal of the Chinese Institute of Industrial Engineers, 2011. 28(4): p. 281-297.

[3] Yaobao, Z., H. Ping, and Y. Shu, An improved particle swarm optimization for the automobile spare part warehouse location problem. Mathematical Problems in Engineering, 2013. 2013.

[4] Quintanilla, S., et al., Heuristic algorithms for a storage location assignment problem in a chaotic warehouse. Engineering Optimization, 2015. 47(10): p. 1405-1422.

[5] Rath, S. and W.J. Gutjahr, A math-heuristic for the warehouse location-routing problem in disaster relief. Computers \& Operations Research, 2014. 42: p. 25-39.

[6] Pulido, R., J.C. Muñoz, and P. Gazmuri, A continuous approximation model for locating warehouses and designing physical and timely distribution strategies for home delivery. EURO Journal on Transportation and Logistics, 2015. 4(4): p. 399-419.

[7] ALBAYRAK, Ö. and B. ERKAYMAN, BULANIK DEMATEL VE EDAS YÖNTEMLERİ KULLANILARAK SPORCULAR İÇIN AKILLI BİLEKLIKK SEÇİİ. Ergonomi. 1(2): p. 92-102.

[8] Erkayman, B., M. Khorshidi, and B. Usanmaz, AN INTEGRATED FUZZY APPROACH FOR ERP DEPLOYMENT STRATEGY SELECTION UNDER CONFLICTING CRITERIA. Atatürk Üniversitesi İktisadi ve İdari Bilimler Dergisi, 2018. 32(3): p. 807-823.

[9] Adar, T. and E.K. Delice, New integrated approaches based on MC-HFLTS for healthcare waste treatment technology selection. Journal of Enterprise Information Management, 2019.

[10] Adar, T., et al., SELECTION OF ON-SITE ENERGY GENERATION TECHNOLOGY WITH A NEW MCDM APPROACH USING MABAC \& AHP. Jaffar Beikzad and Amir Gharifard/5, 2017: p. 126.

[11] Erkayman, B. and F.M. Özkal, Evaluation of framed building types based on the combination of fuzzy AHP and fuzzy MOORA methods. CHALLENGE, 2016. 2(2): p. 101-108.

[12] Erkayman, B., E. Gundogar, and A. Y1lmaz, An integrated fuzzy approach for strategic alliance partner selection in third-party logistics. The Scientific World Journal, 2012. 2012.

[13] Erkayman, B., et al., A fuzzy TOPSIS approach for logistics center location selection. Journal of Business Case Studies (JBCS), 2011. 7(3): p. 49-54.

[14] Emec, S., et al., An Integrated MCDM for a Medical Company Selection in Health Sector.

[15] Adar, T. and E.K. Delice, IJSOM. Int J Supply Oper Manage (IJSOM). 6(3).

[16] Delice, E.K., et al., A Comprehensive Analysis of Location Selection Problem for Underground Waste Containers Using Integrated MC-HFLTS\&MAIRCA and MABAC Methods. Avrupa Bilim ve Teknoloji Dergisi, 2019: p. 15-33.

[17] Emeç, Ş. and G. Akkaya, Stochastic AHP and fuzzy VIKOR approach for warehouse location selection problem. Journal of Enterprise Information Management, 2018. 31(6): p. 950-962.

[18] Akkaya, G., B. Turanoğlu, and S. Öztaş, An integrated fuzzy AHP and fuzzy MOORA approach to the problem of industrial engineering sector choosing. Expert Systems with Applications, 2015. 42(24): p. 9565-9573.

[19] Akkaya, G., Analitik Hiyerarşi Yöntemi İle Personel Seçimi ve Bir Uygulama. Verimlilik Dergisi, 2010(4).

[20] Guneri, A., F. Tiryaki, and G. Akkaya, Using analytic hierarchy process (AHP) in location selection for a yarn factory: A case study. 2006. 
[21] Yuna, F., A Hybrid Fuzzy Multi-Criteria Decision-Making Approach for Data Center Location Selection. Brilliant Engineering, 2019. 1(1): p. 13-20.

[22] Vatansever, K. and M. Uluköy, Kurumsal kaynak planlaması sistemlerinin bulanık ahp ve bulanık moora yöntemleriyle seçimi: Üretim sektöründe bir uygulama. Celal Bayar Üniversitesi Sosyal Bilimler Dergisi, 2013. 11(2): p. 274-293.

[23] Karande, P. and S. Chakraborty, Application of multi-objective optimization on the basis of ratio analysis (MOORA) method for materials selection. Materials \& Design, 2012. 37: p. 317-324.

*Corresponding author.

E-mail address: seyma.yayla@ atauni.edu.tr 